\title{
The Effect of Welding Parameters on the Properties of Join between Studs and Steel Sheet USIBOR Type 22MnB5
}

Pavol Sejč, Judita Belanová

Faculty of Mechanical Engineering, Slovak University of Technology in Bratislava, Nám.Slobody17, 81231 Bratislava. Slovak Republic. E-mail: pavol.sejc@stuba.sk, judita.belanova@stuba.sk

To build the car body parts of today's cars, materials of higher strength are used on an ever-wider scale. They are, for example, boron-containing steels, which are highly resistant to special thermo-mechanical processing, coated with AISi; e.g. USIBOR 22MnB5 type materials. For the final assembly of all body mounting components, it is necessary to apply different types of joining stud elements. One of the possibilities of making joinings between sheets and fastening elements - studs is the technology of short-circuit stud welding

This article aims to evaluate the influence of welding parameters of steel studs on high-strength steel sheet type USIBOR 22MnB5 with AISi coating on selected mechanical properties of joints.

Keywords: Ultra-high strength steel (UHSS), stud welding, strength of welding joint

\section{Introduction}

The current trend in car body components is focused on the application of different types of materials. The most widely used materials include steel sheets with different properties: Carbon-Manganese Steels, Bake Hardening Steels, Dual Phase Steels, Complex Phase Steels, Ferritic-Bainitic Steels, Martensitic Steels, and Ultra High Strength Steels (UHSS-B). The high strength of UHSS steels is obtained not only by alloying, but also by special thermo-mechanical processes. Depending on the type of thermo-mechanical processing, the yield strength and the tensile strength of the material can reach a wide range. The yield strength starts at approximately $430 \mathrm{MPa}$ and after processing and with $\mathrm{BH}$ (Bake Hardening) effect it reaches up to $1770 \mathrm{MPa}$. The tensile strength limit is then $500 \div 2034 \mathrm{MPa}$ [1]. Due to the nature of the heat treatment, UHSS steels are coated with Al-Si coating.

In addition to joints between thin sheet metal stampings, we also find weld joints between the sheet metal on the various types of fasteners - nuts, bolts, studs welded by protrusion resistance welding or some of the stud welding processes $[6,2,5]$. For studs with a lower shaft diameter (2 - $25 \mathrm{~mm})$, the Short-Cycle Stud Welding process is used (marking according to STN EN ISO 4063 is: 784). This is a special drawn-arc stud-welding process with a very short weld time without ferrule. The benefit of "ferruleless" welding is that it lends itself to automatization. The size of the welding current is given by the transformer design and ranges from 400 to $2600 \mathrm{~A}$. The voltage drop across the arc is about $25 \mathrm{~V}$. The welding time is set from 0.005 to 1 second and is selected according to the diameter of the stud, the thickness of the welded sheet and the welding current. Stud welding uses a direct current reverse polarity connection. It is possible to weld the combination of materials: carbon steel, stainless steel and refractory steel $[3,4,7,9,10]$.

This article aims to evaluate the influence of welding parameters of steel studs on high-strength steel sheet type: USIBOR 22MnB5 with AlSi coating on selected mechanical properties of joints.

\section{The methodology of experiments and experi- mental material}

A high strength steel plate, Usibor $22 \mathrm{MnB} 5+\mathrm{AS} 150$ (EN 10131-2.0), $1.4 \mathrm{~mm}$ thick after thermo-mechanical treatment, which corresponds to hot pressing, was used to manufacture the welded test joints. The thickness of the AlSi protective coating measured on the cross sections of the metallographic cuttings ranged from 25 to $30 \mu \mathrm{m}$. The chemical composition and mechanical properties are shown in table1.and 2 .

Tab. 1 Chemical composition of USIBOR 22MnB5

\begin{tabular}{|c|c|c|c|c|c|c|c|c|c|}
\hline Element (\%) & $\mathrm{Al}$ & $\mathrm{B}$ & $\mathrm{C}$ & $\mathrm{Cr}$ & $\mathrm{Mn}$ & $\mathrm{N}$ & $\mathrm{Ni}$ & $\mathrm{Si}$ & $\mathrm{Ti}$ \\
\hline $22 \mathrm{MnB} 5$ & 0.03 & 0.002 & 0.23 & 0.16 & 1.18 & 0.005 & 0.12 & 0.22 & 0.04 \\
\hline
\end{tabular}

Tab. 2 Mechanical properties of Usibor $22 \mathrm{MnB5}$

\begin{tabular}{|c|c|c|c|}
\hline Properties & $\mathrm{Rp}_{0,2}(\mathrm{MPa})$ & $\mathrm{R}_{\mathrm{m}}(\mathrm{MPa})$ & $\mathrm{A}_{80} \min .(\%)$ \\
\hline $22 \mathrm{MnB} 5$ & $350-550$ & $500-700$ & 10 \\
\hline
\end{tabular}

Steel studs of diameter $\varnothing \mathrm{d}=6 \mathrm{~mm}$, length $1=23 \mathrm{~mm}$ (designation: PS M6x23) were welded to the plate. The chemical composition of stud steel is shown in Table. 3 .

Tab. 3 Chemical composition of stud steel

\begin{tabular}{|c|c|c|c|c|c|c|}
\hline Element (\%) & $\mathrm{C}$ & $\mathrm{Si}$ & $\mathrm{Mn}$ & $\mathrm{P}$ & $\mathrm{S}$ & $\mathrm{Al}$ \\
\hline PS M6x23 & $0.08-0.12$ & 0.10 & $0.30-0.50$ & 0.025 & 0.025 & $0.02-0.06$ \\
\hline
\end{tabular}

Welding equipment was used by Emhart Tucker, a welding head type: LM 310 in combination with the TMP 1500 control unit. The welding parameters set during the joining process were measured by the Matuschek SPATZ
Multi04 measuring devices. From the measured welding current, welding voltage and welding time values, the heat input (mean power) was calculated according to (1): 
Where:

$$
Q=U . I . t \quad(J)
$$

$\mathrm{U}$ is the measured voltage value $[\mathrm{V}]$,

I - Measured welding current [A],

$\mathrm{t}$ - Welding time $[\mathrm{s}]$.

Tests were performed on the samples:

- Shear strength tests using a torque wrench

- Tensile strength test

- Vickers test of hardness

- Macro and microstructure assessment by light microscopy.

The results obtained were evaluated according to the internal standard VW SK-PV 1606.

\section{Achieved results}

A series of test samples with different stud welding parameters (Table 4.) was made to evaluate the influence of the process variables on the joints properties. By changing the welding current setting (from 510 to 1300
A) and the welding time (from 0.020 to $0.045 \mathrm{~s}$ ), we have achieved a different heat input to the weld (from 185 to $1096 \mathrm{~J})$.

Table 5. shows the images of the tested samples: a side view of the weld joint, a front view of the stud as well as a view from the opposite side of the welded sheet.

Tab. 4 Set and measured (calculated) values of stud welding parameters

\begin{tabular}{|c|c|c|c|c|c|}
\hline \multirow{2}{*}{$\begin{array}{c}\text { Series } \\
\text { number }\end{array}$} & \multicolumn{2}{|c|}{ Set values } & \multicolumn{3}{c|}{$\begin{array}{c}\text { Measured (calculated) av- } \\
\text { erage values }\end{array}$} \\
\cline { 2 - 6 } & $\mathrm{I}^{*}(\mathrm{~A})$ & $\mathrm{t}(\mathrm{ms})$ & $\mathrm{I}(\mathrm{A})$ & $\begin{array}{c}\mathrm{U} \\
(\mathrm{V})\end{array}$ & $\mathrm{Q}(\mathrm{J})$ \\
\hline 1 & 510 & 20 & 508.2 & 18.3 & 186.00 \\
\hline 2 & 610 & 25 & 607.9 & 18.2 & 276.59 \\
\hline 3 & 710 & 30 & 707.7 & 18.4 & 390.65 \\
\hline 4 & 810 & 30 & 806.1 & 18.6 & 449.78 \\
\hline 5 & 910 & 35 & 906.5 & 18.3 & 580.61 \\
\hline 6 & 1100 & 40 & 1097.3 & 18.7 & 820.74 \\
\hline 7 & 1300 & 45 & 1295.0 & 18.9 & 1101.40 \\
\hline
\end{tabular}

Tab. 5 Overall view of welded joints made with different welding parameters

\begin{tabular}{|c|c|c|c|}
\hline $\begin{array}{l}\text { Series } \\
\text { number }\end{array}$ & Side view & Front view & Back view \\
\hline 1 & & & \\
\hline 2 & & & \\
\hline 3 & & & \\
\hline 4 & & & \\
\hline 5 & & & \\
\hline 6 & 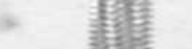 & & \\
\hline 7 & & & \\
\hline
\end{tabular}


Tab. 6 Results of torque wrench test

\begin{tabular}{|c|c|c|c|c|c|c|c|c|c|c|c|c|c|}
\hline Sample & $\begin{array}{c}\text { Mo } \\
\text { (N.m) } \\
\end{array}$ & \begin{tabular}{|c|}
$\begin{array}{c}\text { Sam } \\
\text { ple }\end{array}$ \\
\end{tabular} & $\begin{array}{c}\text { Mo } \\
\text { (N.m) }\end{array}$ & \begin{tabular}{|c|}
$\begin{array}{c}\text { Sam } \\
\text { ple }\end{array}$ \\
\end{tabular} & $\begin{array}{c}\text { Mo } \\
\text { (N.m) }\end{array}$ & Sample & $\begin{array}{c}\text { Mo } \\
\text { (N.m) }\end{array}$ & Sample & $\begin{array}{c}\text { Mo } \\
\text { (N.m) }\end{array}$ & Sample & $\begin{array}{c}\text { Mo } \\
\text { (N.m) }\end{array}$ & Sample & $\begin{array}{c}\text { Mo } \\
\text { (N.m) }\end{array}$ \\
\hline $1 \mathrm{a}$ & 3.10 & $2 \mathrm{a}$ & 4.38 & $3 a$ & 16.56 & $4 a$ & 15.91 & $5 a$ & 19.35 & $6 a$ & 17.54 & $7 \mathrm{a}$ & 15.21 \\
\hline $1 b$ & 3.26 & $2 b$ & 4.22 & $3 b$ & 14.92 & $4 \mathrm{~b}$ & 16.77 & $5 b$ & 20.72 & $6 \mathrm{~b}$ & 16.16 & $7 \mathrm{~b}$ & 17.02 \\
\hline $1 \mathrm{c}$ & 3.24 & $2 c$ & 3.87 & $3 c$ & 16.64 & $4 c$ & 16.64 & $5 c$ & 18.01 & $6 c$ & 18.92 & $7 \mathrm{c}$ & 16.81 \\
\hline $\begin{array}{l}\text { Aver- } \\
\text { age }\end{array}$ & 3.20 & & 4.16 & & 16.04 & & 16.44 & & 19.36 & & 17.54 & & 16.35 \\
\hline $\begin{array}{l}\text { Stand- } \\
\text { ard de- } \\
\text { viation }\end{array}$ & 0.09 & & 0.26 & & 0.97 & & 0.46 & & 1.35 & & 0.97 & & 0.99 \\
\hline $\begin{array}{c}\text { Fulfil- } \\
\text { ment } \\
\text { accord- } \\
\text { ing } \\
\text { stand- } \\
\text { ard : } \\
\text { VW } \\
\text { SK- } \\
\text { PV } \\
1606 \\
\end{array}$ & No & & No & & Yes & & Yes & & Yes & & Yes & & Yes \\
\hline
\end{tabular}

The view from the side to the welding joint site documents primarily the effect of the heat input on the melting range of the contact head of the welded stud. At lower heat inputs (up to $\mathrm{Q}=580 \mathrm{~J}$ ), only local melting of the contact surface of the stud occurred without significant change in head height. At higher heat inputs, a significant deformation of the welded stud head can be observed. In the 7-series sample, because of the high overheating and the effect of the compressive force in the final phase of the joining process, the entire volume of the contact head of the welded stud was deformed. As shown in the front view of the stud, at the maximum heat input applied $(\mathrm{Q}=$ $1101 \mathrm{~J}$, Table 4.), the molten metal of the stud material has already spattered from the joint area. Spatter can then be the cause of internal joints defect - porosity, respectively shrinkage. The front view of the welded studs (Table 5.) documents a smaller or larger area of a black smut. This is due to the absence of a shielding gas during welding.

Images from the back side of the joint (welded sheet side) show that even at the highest heat input of the welding, the protective Al-Si layer of the UHSS sheet was not damaged. Similarly, no significant deformation at the joining site of the USIBOR 22MnB5 sheet was found at visual inspection. The test of the mechanical properties of the torque wrench can be either non-destructive, i.e. the joint is tested for the prescribed torque according to the weld documentation or a destructive test at which the maximum torque is measured, causing mechanical damage to the test joint. The prescribed torque load of the stud according to the internal VW standard SK-PV 1606- for the stud used is $6[\mathrm{Nm}]$.

The results of the destructive test with the evaluation of the obtained results according to the internal standard are in Table. 6.

From the results obtained, it is clear that the samples from series 1 and 2 (used average heat input $Q=186$ and $276 \mathrm{~J})$ did not meet the shear strength requirements. The remaining samples (series 3 to 7) met the requirements of the internal standard. The torque values for weld failure have exceeded the required value two to three times. In all cases, the fracture area was located in the weld metal zone. (Figure 1.)

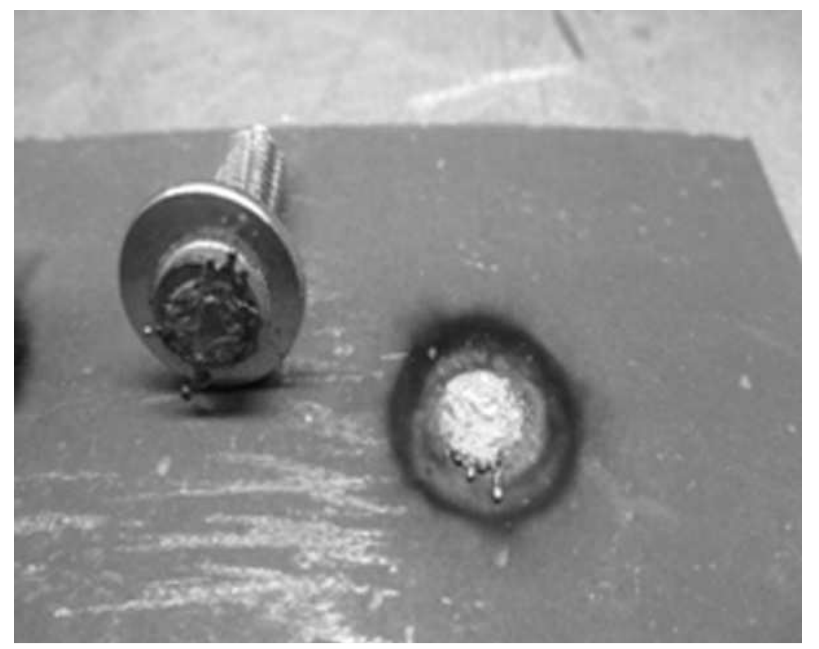

Fig. 1 Sample 3 after a torque wrench test

The tensile strength test results are shown in Table 7. According to the internal standard, the minimum load force for failure of the joint $\mathrm{F}=2192 \mathrm{~N}$ is prescribed for used type of studs. From the results obtained, it is obvious that the process parameters of the series 1 and 2 series joints (Table 4.) are also unsatisfactory in terms of tensile strength of the welded joints. The maximum load force in the event of breaking the integrity of the joint in these cases did not reach the minimum required value. Samples made by heat input greater than $\mathrm{Q}=390 \mathrm{~J}$ (Series 3 to 7, Table 4.) again met the tensile strength requirements according to the internal standard VW SK-PV 1606. As with the torque wrench test, the joint integrity was failed in weld metal zone after the tensile strength test. 
Tab. 7 Results of the tensile strenght test

\begin{tabular}{|c|c|c|c|}
\hline Series number & $\begin{array}{l}\text { Min. load force for failure } \\
F_{\text {prescribed }}(\mathrm{N})\end{array}$ & $\begin{array}{l}\text { Fracture load } \\
\mathrm{F}_{\max }(\mathrm{N})\end{array}$ & $\begin{array}{l}\text { Fulfillment according standard: } \\
\text { VW SK- PV } 1606\end{array}$ \\
\hline 1 & \multirow{7}{*}{2192} & 1639.45 & No \\
\hline 2 & & 2158.83 & No \\
\hline 3 & & 2481.43 & Yes \\
\hline 4 & & 4961.18 & Yes \\
\hline 5 & & 8114.95 & Yes \\
\hline 6 & & 9141.35 & Yes \\
\hline 7 & & 8562,85 & Yes \\
\hline
\end{tabular}

For the macroscopic analysis of the joints, the following samples were selected: a series 3 sample prepared by the parameters: $\mathrm{I}=710 \mathrm{~A}$ at $=30 \mathrm{~ms}$ (Figures 2. and 3.) and a series 6 sample made by parameters $\mathrm{I}=1100 \mathrm{~A}$ at $=40 \mathrm{~ms}$ (Figures 4. and 5.). Series 3 samples conformed to the VW internal standards when tested with torque wrench and tensile strength test using a minimum welding heat input $(Q=390 \mathrm{~J})$. Series 6 samples exhibited maximum shear and tensile strength values in the tests the heat input used here was more than 2 times $(\mathrm{Q}=820$ J) compared to the series 3 samples.

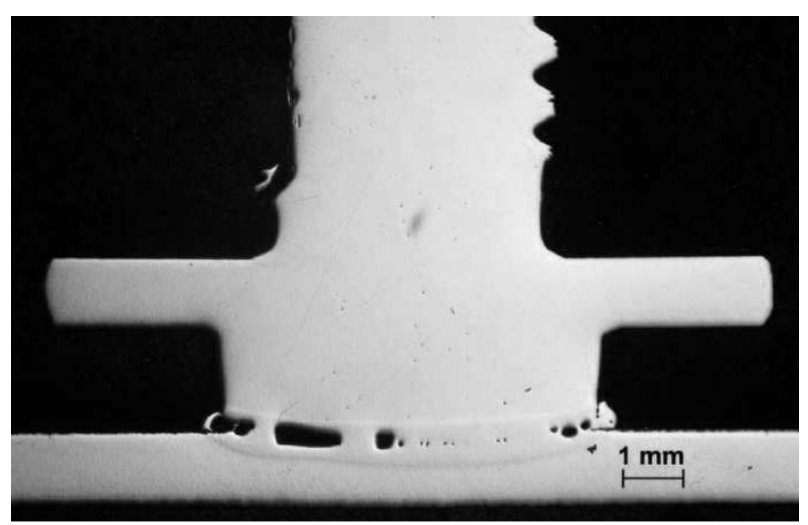

Fig. 2 Cross-section of sample 3, polished.

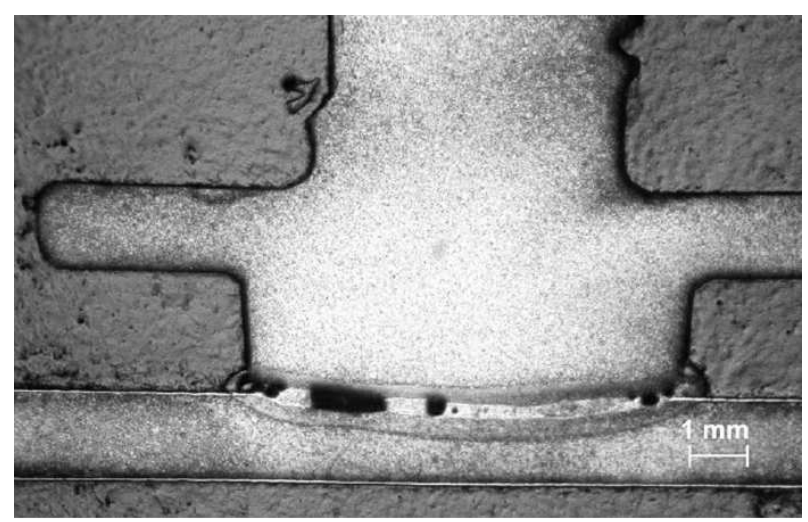

Fig. 3 Cross-section of sample 3, etched $3 \%$ Nital

In Fig. 2. and 3., a series 3 sample, there are clearly visible defects in the welding joint: porosity, and shrinkage in the weld metal zone. Large pores were mainly found at the edge of the weld metal, the small pore localization copied the original interface between the stud and the UHSS sheets. A part of the molten weld metal was pushed into the flash during welding. The rounded shape of the observed defects will not produce significant stress concentration. Reduction of the cross-section of the joint (in the indicated area, the reduction of the cross-sectional area by more than $1 / 7$ ) was manifested by lowering the strength of the welding joint of the series 3 samples (Tables. 6 . and 7).

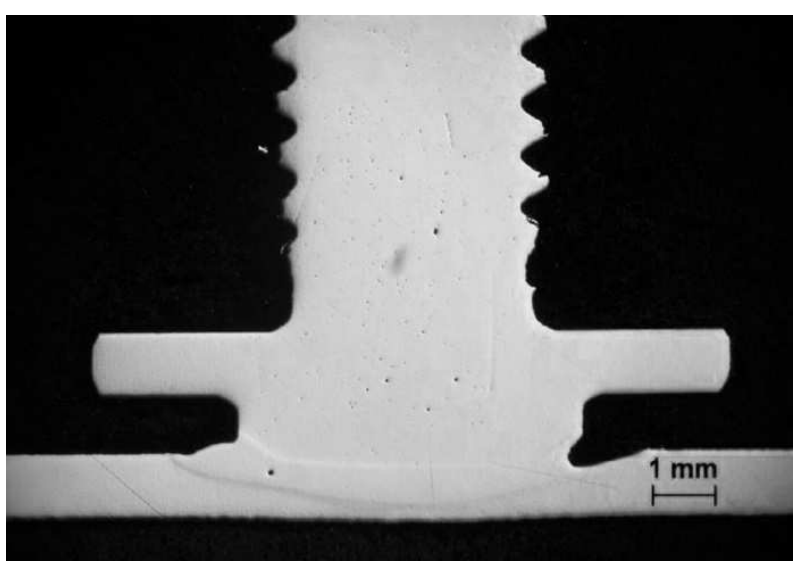

Fig. 4 Cross-section of sample 6, polished

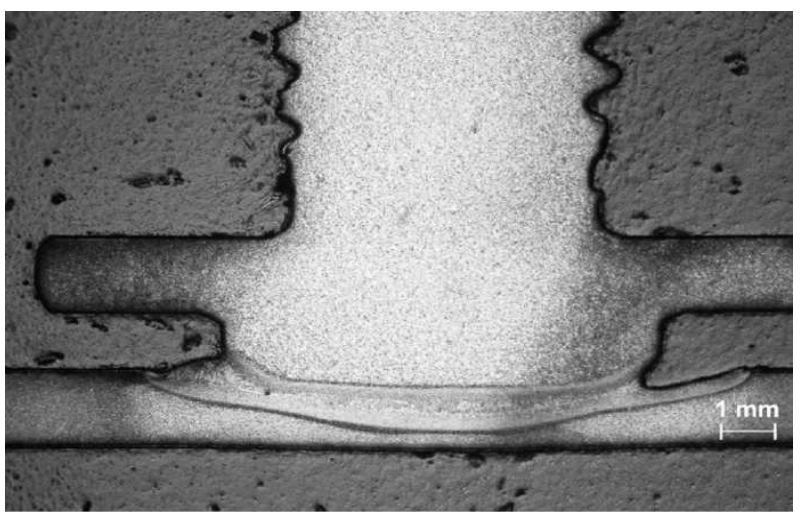

Fig. 5 Cross-section of sample 6, etched $3 \%$ Nital

In Fig. 4. and 5., a sample of the series 6, the welding joint can be seen with minimal defects. The joining of the welded parts is slightly asymmetrical, with the incidence of lack of fusion on the left side of the weld. The unique pores, once again in the area of the original interface between the stud and the UHSS plate, had no significant influence on the strength properties of the weld joint, which also confirmed the results of the tests performed (tab. 6 . and 7.).

Joint structure analysis was performed on sample $3 \mathrm{~A}$. Detail of the individual areas (WM, HAZ from the side USIBOR 22MnB5 and the welded steel stud, BM) are in Fig. 6. and 7.

The structure evaluation was completed by measuring the hardness HV 0.2 (fig. 8.). 


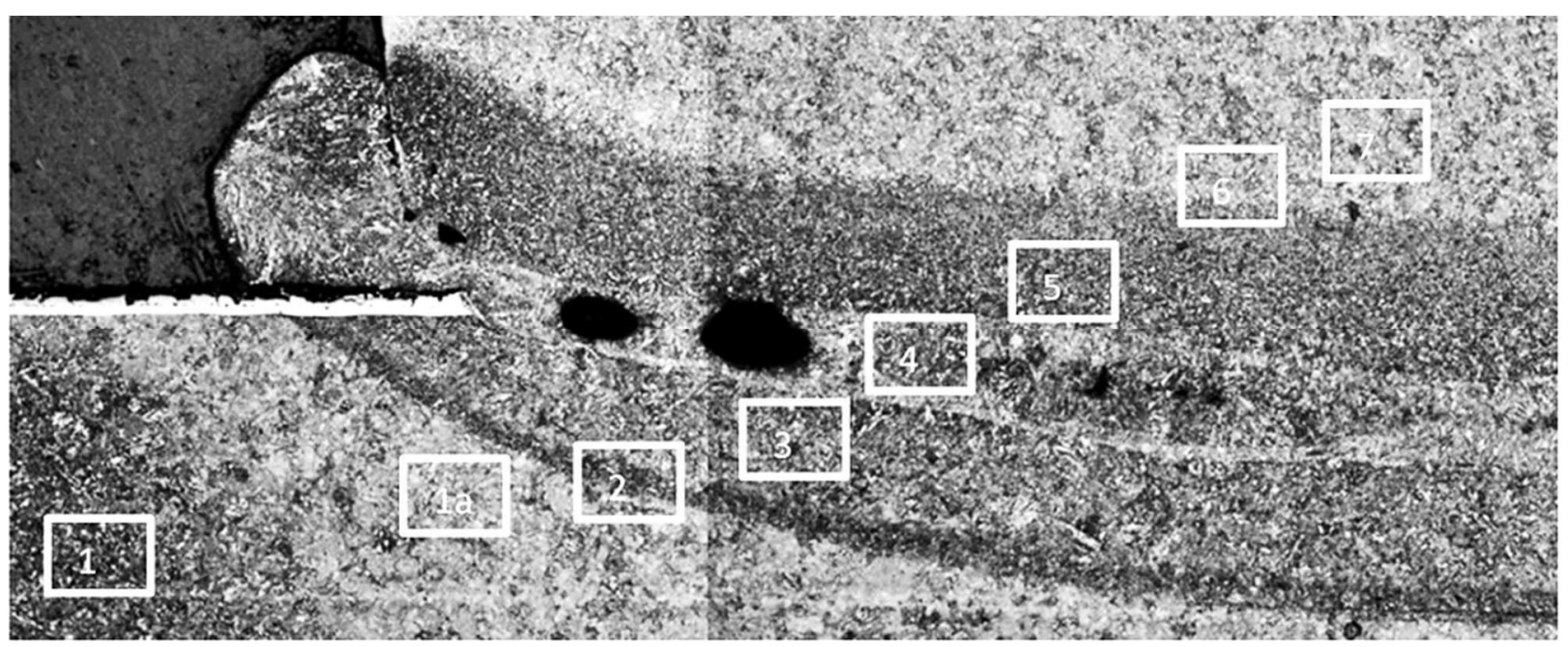

Fig. 6 Cross-section detail of the sample 3: 1 - USIBOR 22MnB5, 1a-subcritical HAZ of USIBOR 22MnB5, 2 intercritical HAZ of USIBOR 22MnB5, 3 - supercritical HAZ of USIBOR 22MnB5, 4-weld metal (WM), 5 supercritical HAZ of steel stud, 6-intercritical HAZ of steel stud, 7 - steel stud.

The structure of the USIBOR 22MnB5 base material consisted of martensite and retained austenite (Fig. 7a), corresponding to an average hardness of $493 \mathrm{HV} 0.2$. In the area heated during the welding temperature cycle just below the temperature of $\mathrm{A}_{\mathrm{c} 1}$ - subcritical HAZ (Fig.7b), there was a marked decrease in hardness (Fig. 8.). The structure consisting of ferrite and tempered martensite showed a hardness of only 345 to $312 \mathrm{HV} 0.2$. In intercritical HAZ with partial structure recrystallization (Fig.7c), at temperatures between the $\mathrm{A}_{\mathrm{c} 3}$ and $\mathrm{A}_{\mathrm{c} 1}$ lines in the heating phase, the USIBOR 22MnB5 structure was partially austenitized. The austenite was subsequently transformed into martensite at a high rate of cooling to produce a martensitic-ferritic structure with an average hardness of $360 \mathrm{HV} 0.2$. The maximum hardness in the welding joint structure, 520HV0.2, was measured in the supercrical grain growth region by the USIBOR 22MnB5 plate (Fig. 8.). The dominated martensite structure (Fig. 7d) was formed by a transformation of austenite, overheated to high $\mathrm{A}_{\mathrm{c} 3}$ temperature, during rapid cooling. [11].

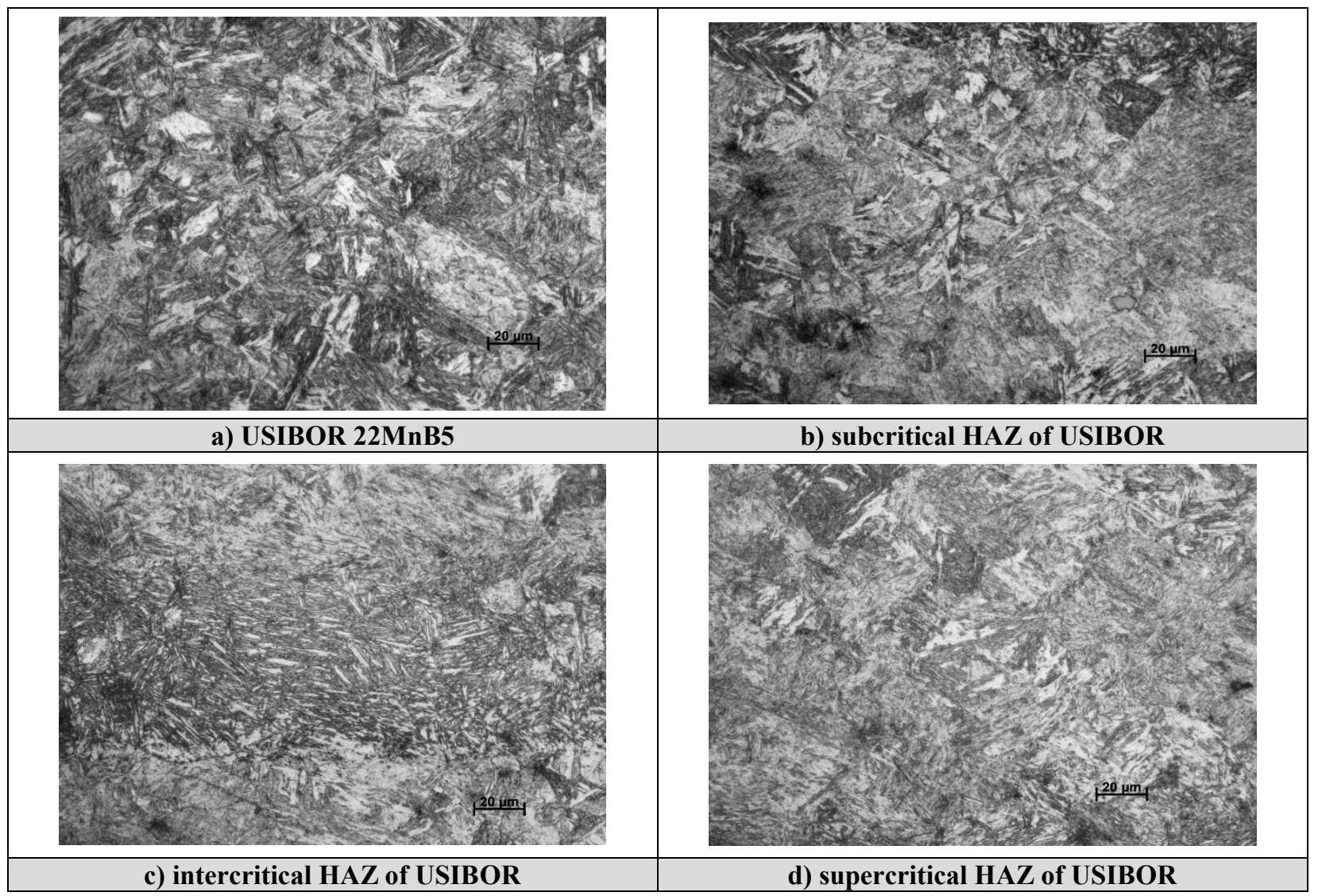




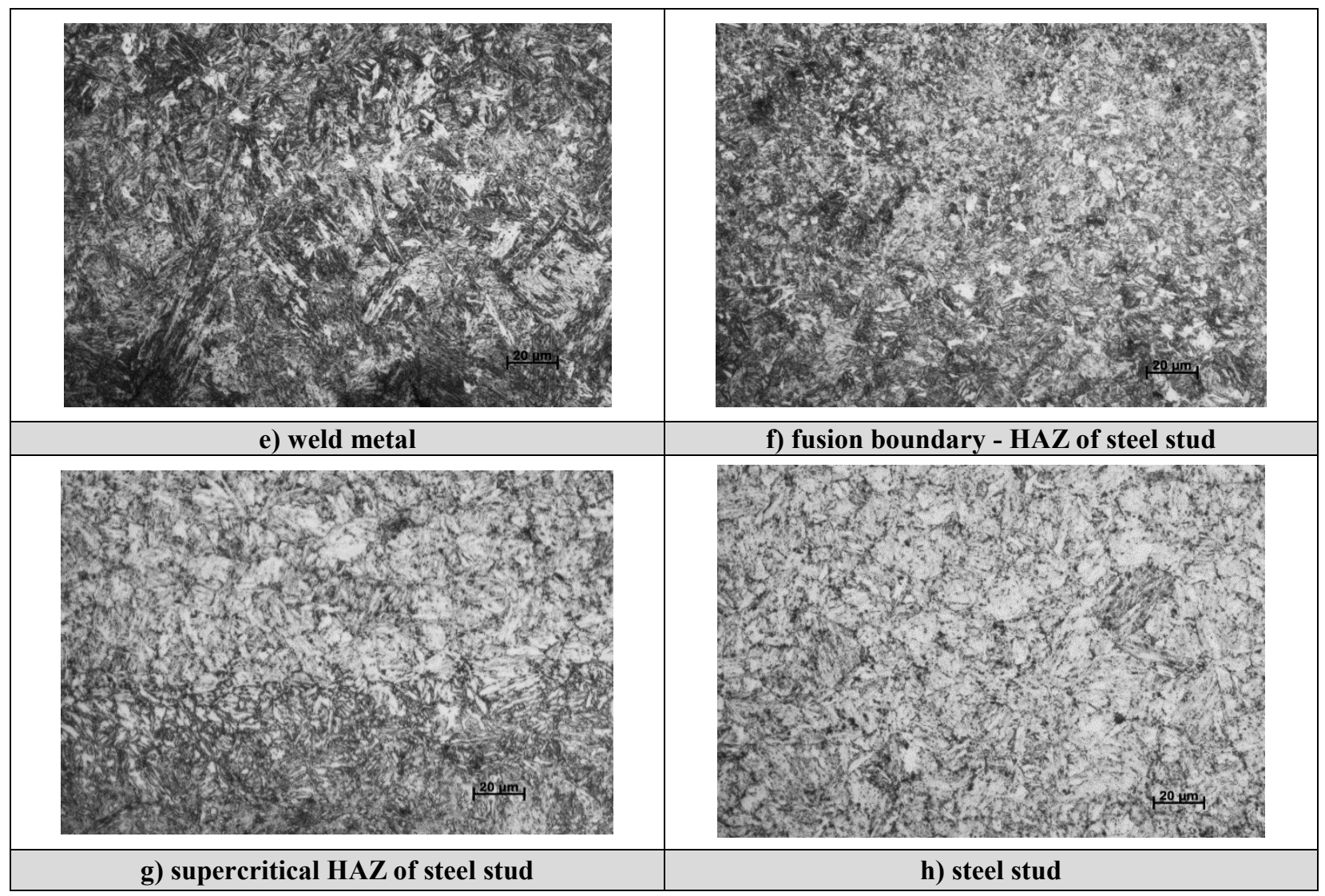

Fig. 7 Details of each individual areas structure

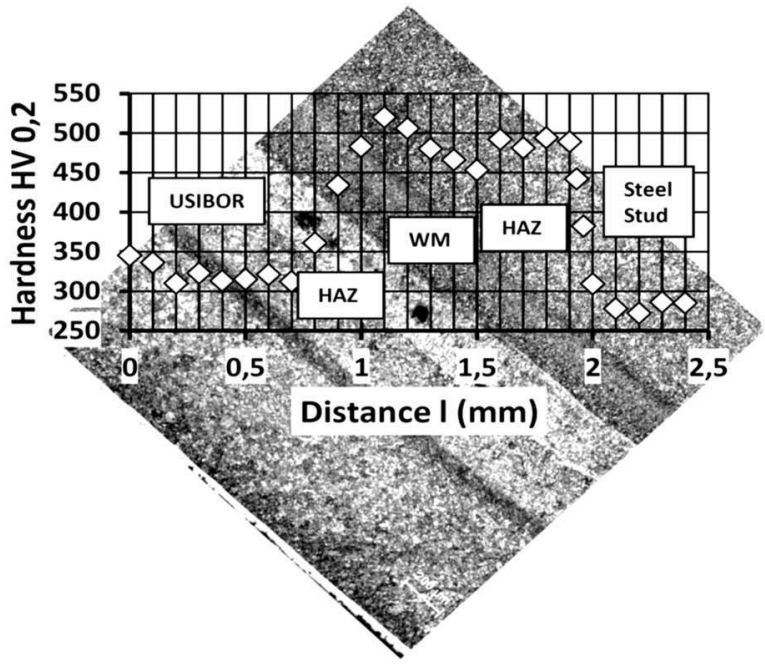

Fig. 8 Hardness of the selected areas of the welding joint

The subsequent decrease in hardness in the weld metal zone was caused, first of all, by mixing the molten high carbon steel material (USIBOR 22MnB5) and the stud metal (unalloyed low carbon steel). Thus, the carbon content in WM was reduced as compared to its presence in USIBOR 22MnB5 (Table 1.), which affected the hardness of the weld metal. The martensitic structure of the weld metal (Fig.7e) with an average hardness of 480HV0.2 had only a slightly lower hardness than the thermal non affected base material USIBOR 22MnB5 (493HV 0.2).
The HAZ structure of the stud was affected not only by the high cooling rate but also by changes in the chemical composition, especially in the carbon content. Mixing a low carbon (non-alloy) steel material with a higher carbon content steel (USIBOR 22MnB5 + AS150) in the weld metal resulted in the formation of a martensitic structure with high hardness. Thus, we can assume that at high welding temperatures there will be diffusion of carbon from weld metal to the supercritical HAZ of low carbon steel stud. Carburization and overheating of the material at high temperature will result in the formation of a multiphase structure with the predominant presence of martensite and upper bainite (Fig.7f). This also corresponds to the hardness of the supercritical HAZ, whose average value was $480 \mathrm{HV} 0.2$ (Figure 8.). A marked drop in hardness was observed in the intercritical HAZ on the side of the steel stud. The structure change to ferrite + transformed pearlite (Fig. $7 \mathrm{~g}$ ) resulted in a decrease of the total hardness of the structure to $310 \mathrm{HV} 0.2$ (Fig. 8.) The ferrite-pearlite structure of the steel stud is shown in Fig. $7 \mathrm{~h}$. The average hardness of thermal non-affected BM was $280 \mathrm{HV} 0.2$.

\section{Conclusion}

The submitted paper is focused on evaluation of the impact of steel stud welding parameters on high-strength steel sheet of type USIBOR 22MnB5 with AlSi coating for selected mechanical properties of joints. The influence of heat input on the shear strength of the joints (evaluated by the torque wrench test) and the tensile strength 
(assessed by the static tensile strength test) were examined. The results obtained were compared with the requirements of the internal standard VW SK-PV 1606. The evaluation was supplemented by analysis of the structure of the welding joint. The following conclusions can be drawn from the results:

- For the strength ratings of welded joints according to the VW standard, it can be stated that for the selected sheet type (USIBOR 22MnB5, thickness $1.4 \mathrm{~mm}$ ) and steel stud $(\varnothing \mathrm{d}=6 \mathrm{~mm}$, length $\mathrm{l}=23 \mathrm{~mm})$ a thermal input for stud welding of at least $\mathrm{Q}=390 \mathrm{~J}$ is needed.

- Another increase in thermal input has been shown to increase the strength properties of the joint (Fig. 9.). The trend of assessing the influence of heat input on shear and tensile strength was equal to $\mathrm{Q}=600 \mathrm{~J}$. Above this value we noticed a decrease in the shear strength. The maximum tensile strength, on the other hand, was measured on heat-welded samples $\mathrm{Q}=820 \mathrm{~J}$.

- From the structure analysis supplemented by microhardness measurement, a significant difference was found between the subcritical heat affected zone from the USIBOR 22MnB5 plate and the steel stud and the intercritical HAZ on both sides of the welded materials. From the USIBOR 22MnB5 sheet side, a hardness increase from $312 \mathrm{HV} 0.2$ to $434 \mathrm{HV} 0.2$ occurred in the intercritical zone, from the steel stud side of $309 \mathrm{HV} 0.2$ to 494HV0.2. The maximum hardness of the structure $520 \mathrm{HV} 0.2$ was measured in the supercritical HAZ of USIBOR 22MnB5 material, which can be considered critical from the point of view of susceptibility to cracks from the decrease in toughness. The WM and HAZ structure both from the USIBOR 22MnB5 sheet and from the steel stud side was predominantly martensite. The subcritical HAZ of USIBOR 22MnB5 welded sheet metal formed martensite, which on the side of the steel stud was ferrite and transformed pearlite.

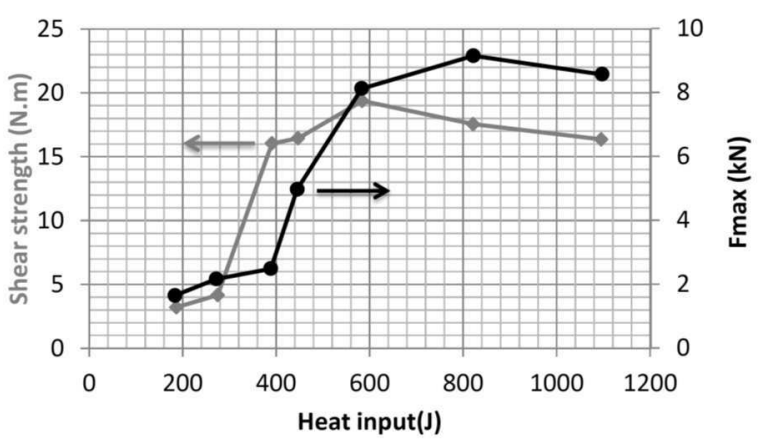

Fig. 9 The influence of heat input on shear and tensile strength of welds $\left(F_{\max }\right)$

\section{Acknowledgement}

The results given in this paper were obtained as part of VEGA 1/0405/19 research project. Support of the UVP
STU Bratislava ITMS 26240220084 project is also acknowledged.

\section{References}

[1] MATTHEWS, A. E., DAVIES, G. M. (1997). Precoated steel development for the automotive industry. In: Proceedings of the institution of mechanical engineers, 211, Part D, pp.319-324.

[2] CARY, H. B., HELZER, S. C. (2005). Modern welding technology. Pearson Prentice Hall, New Jersey, ISBN 0-13-113029-3.

[3] Welding Handbook, Eighth Edition (1991). V. 2, Welding Processes, Chapter 9, Stud Welding. American Welding Society, Miami, Fl, pp. 300 327

[4] CHAMBERS, A.H. (2001). Principles and Practices of Stud Welding, PCI Journal Vol. 46, No 5, pp. 46-58.

[5] HSU, C., MUMAW, J. (2011). Weldability of Advanced High-Strength Steel Drawn Arc Stud Welding. Welding journal, march, VOL. 90, pp. $45-53$

[6] HONGYAN, Z., SENKARA J. (2017). Resistance Welding: Fundamentals and Applications, 2nd Edition CRC Press, Published March 31,456 Pages.

[7] http://www.antec.com.au/media/downloads/stud welding catalogue.pdf. Available on web.(24.10.2018)

[8] YILMAZ, N. F., HAMZA, A., (2014). Effect of Process Parameters on Mechanical Properties of Arc Stud Weld. Materialprufung - October 2014, 56 (2014) 10,pp. $806-811$

[9] SHOME, M., TUMULURU, M., (2015). Welding and Joining of Advanced High Strength Steels (AHSS). 1st Edition, Woodhead Publishing, , Page Count: 204, ISBN: 9780857094360

[10] DOBROCKY, D., DOSTAL, P., SUSTR, M., POKORNY, Z., STUDENY, Z., (2018). Anylysis of Weld Joint of DX51D Steel with AlMg3 Alloy Made by CMT Welding Method. In: Manufacturing Technology, Vol.18, No.2, pp. 215-221, Czech Republic.

[11] BUBLIKOVA, D., MASEK, I., VOREL, I., JENICEK, Š. (2017). Stability of Retained Austenite in High-Strength Martensitic Steels with Low Ms Teperature. In: Manufacturing Technology, Vol.17, No.4, pp. 428-433, Czech Republic. 